Agricultural Journal 5 (4): 264-268, 2010

ISSN: $1816-9155$

(C) Medwell Journals, 2010

\title{
Determinants of Adoption of New Technologies and the Role of Credit in the Production of Rice in Benue State, Nigeria
}

\author{
Odoemenem Innocent Uwaegbuonu \\ Centre for Food and Agricultural Strategy, University of Agriculture, \\ P.M.B. 2373, Makurdi, Benue State, Nigeria
}

\begin{abstract}
In the past years, rice has become an important component of Nigeria's food import statistics. In fact, no other single crop appears to attract so much government attention as rice does in Nigeria. This study investigated mainly those economic factors which contributed to the adoption of new and improved farm technology. Data were collected from four local government areas of Benue State through interview conducted among a total of 150 small-scale farmers. The data were analyzed using descriptive and inferential statistics. Adoption of improved farm practice may in part be related to the way farmers receive the technologies being introduced to them. Important factors in such a perception are the difficulty inherent in using a practice; the consistency or how adaptable the practice is to existing practices farmers are already familiar with and the returns farmers believe are likely to accrue to them by using the practice. In other to assess the performance of the interviewed farmers and related practices to the environment of the societies, questions were asked with respect to type of rice cultivated, production practices, credit availability and use of fertilizers, insecticides and herbicides. Other factors assessed include the seriousness of conflicts of the times for rice planting and harvesting with other periods of farm work; knowledge and adoption of new innovations.
\end{abstract}

Key words: Adoption, availability of credit, farmers, innovations, inputs, practices, small-scale

\section{INTRODUCTION}

As a food, rice (Halic sativa) has become increasingly important in Nigeria. This is not only of those areas in the country where it has been cultivated for a long time and forms the basis of life of the people but also those areas that have a relatively low rice consumption. The changes in the structure of consumption in conjunction with a growth rate of population have led to a situation where although, there is increase in quality produced, the production can no longer keep pace with the growing demand. As a result, huge sum of foreign exchange is spent on rice importation into the country until recently.

The major problem facing small-scale rice farmers in Benue State is the need to transform their agricultural industry from one depending on traditional inputs with low productivity to one based on modern inputs with higher productivity. There has been a general effort by the State Government and Extension Service agents to encourage small-holder farming in the studied areas. The State Government assists local farmers through the provision of fertilizers and seeds at subsidized rates and the services of agricultural extension workers. The use of simple farm implements like matchets and hoes is still there. There is lack of formal credit facilities to boost agricultural production. It is also widely accepted that to increase rice production in Nigeria, there must be a change in the technology of agricultural production. However, one of the major roles facing agricultural policy makers in this crusade of changing the farm technology of the small-scale farmers in Nigeria centers mainly on the investigation of those economic factors which contribute to the adoption of new and/or improved farm technology. For farmers to adopt an agricultural technology they pass through many stages such as awareness, interest, trial, evaluation and adoption. William (1969), Nweke and Akerhe (1983) and Monu and Omole (1983) stated that extension workers, mass media and individual contact with neighbours proved most effective determinants in adoption process.

Many studies have shown that small-scale farmers have lagged in adoption of the new seed varieties and that there is a close relationship between adoption by small-scale farmers and use of Esusu (indigenous cooperative) credit in many areas. For example, Umebali and Obinna (2003) indicated that Esusu credit was becoming the most important source of agricultural credit. However, the importance of Esusu (indigenous cooperative) credit in adoption is not universal and many aspects of this relationship are ill-defined. Umebali and Obinna (2003) in their study observed that the 
enhancement of agricultural development through the adoption of farm practices was influenced by social and psychological as well as economic factors.

Community standards and social relationships provide the general framework in which the process of change occurs. Differences from individuals help to explain variations in adoption of practices within the community. The more educated an individual is the likely he is to adopt new practices than an individual who has less formal education. Indigenous farm organization and membership of farmers Esusu clubs (indigenous cooperative) are associated with early adoption of new farm practices.

This is so because farmers must have financial back-up to adopt any new innovation. Along the same line comes, the number of contacts which individual farmers have with new ideas through bulletins, farm magazines and newspapers are positively related to early adoption practices.

Ugwuonah (1999) in his appraisal of the sources of finance to agricultural development and innovation in Nsukka local government area of Enugu State, Nigeria found that small-scale farmers who participated in Esusu clubs (indigenous cooperatives) have made good progress in new innovation adoption. He however, stated that age, education, farming experience and the source of information used did not relate to the adoption of new practices.

He further stated that farmers who had more contacts with the extension officers and discussed their farm problems with trusted friends and relatives in the neighbourhood as well as participated in Esusu clubs (indigenous cooperatives) adopted more new practices. Osuntogun (1981) and Otitoju (2004) stated that smallscale farmers adopted farm practices in Gwer West local government area of Benue State, Nigeria because they received the necessary information from the contact agents whom they had confidence.

They also, thought they could make more money by adopting the farm practices. The researchers also observed that lack of credit facilities, specific information about the practices were the reasons for small-scale farmers not adopting most of the prescribed practices.

From the aforementioned, one can say that agricultural development in Nigeria depends to a great extent on the willingness and ability of the small-scale farmers to make use of new technology as developed in research laboratories. New innovations in agricultural development are of little value until they can be put to some practical use for the economic and social well-being of the people involved. The broad objective of this study was to determine the effectiveness of the adoption of new extension innovation on the small-scale farmers of Benue State. Specifically, to examine the extent of adoption of recommended farm practices by small-scale rice farmers to examine the effectiveness of adopted farm practices by the small-scale rice farmers.

\section{MATERIALS AND METHODS}

The study area: Data for this study were collected through interview conducted among a total of 150 small-scale farmers drawn from four local government areas of Benue State, namely, Makurdi, Gwer West, Agatu and Katsina-Ala, all of which are rice producing areas. Benue State is located within longitude $8^{\circ} \mathrm{E}$ and $10^{\circ} \mathrm{E}$ and Latitude $6^{\circ} 30^{\prime} \mathrm{E}$ and $8^{\circ} 10^{\prime} \mathrm{N}$, respectively.

Benue State falls within the middle belt AgroEcological Zone of Nigeria and has an area population of about $43,300 \mathrm{~km}^{2}$ and 4.3 million, respectively. Benue State is bounded in the north by Plateau States and Taraba State in the North Eastern directin. In the South Eastern boundary is Cross-river State while Enugu State is the Southern border of the State. Benue is also bounded in the West by Kogi State. About $75 \%$ of the Benue people are farmers (BNARDA, 2004).

This is explained by the fact that the State is endowed with rich fertile land which encourages the production of arable crops.

Makurdi local government areas has less rainfall as compared with the rest of the local government areas. Rainfall normally commences from April to October with the most rain around May and June. Rainfall decreases from $11.75 \mathrm{~mm}$ inKatsina-ala, $1.70 \mathrm{~mm}$ in Otukpo, $1.700 \mathrm{~mm}$ in Agatu and $1.650 \mathrm{~mm}$ in Makurdi (these are annual totals).

Temperature during the rainy period is $29.7-33.7^{\circ} \mathrm{C}$ $\left(85.4-29.6^{\circ} \mathrm{F}\right)$ maximum and $21.7-24.2^{\circ} \mathrm{C}\left(17.1-75.6^{\circ} \mathrm{F}\right)$ minimum. The relative humidity is about $68 \%$. The questions asked included those aimed at knowing the recommended practices for producing high yielding rice and whether small-scale farmers have heard about improved practices.

The details of the findings are reported within analysis and discussions. Both descriptive and inferential statistics were used to test the selected socio-economic factors on the adoption of production of high-yielding varieties of rice among the selected farmers.

Model specification: In the adoption process, many variables may affect the decision to adopt certain practices. In this study, the following model is formulated to explain some of the determinants of adoption: 
Agric. J., 5 (4): 264-268, 2010

Where:

$$
\mathrm{Y}_{1}=\mathrm{f}\left(\mathrm{X}_{1}, \mathrm{X}_{2}, \mathrm{X}_{3}, \mathrm{X}_{4}, \mathrm{U}\right)
$$

$Y_{1}=$ Adoption of high yielding varieties of rice (adoption index)

$\mathrm{X}_{1}=$ Extension contact (frequency of agents' contacts)

$\mathrm{X}_{3}=$ Esusu (cooperative) credit (in naira)

$\mathrm{X}_{4}=$ Age (years)

$\mathrm{U}=$ Factors affecting the adoption of high-yielding varieties of rice

The model states that the extent of adoption of highyielding varieties of rice will be determined by frequency of extension agents' contact, use of mass communication media exposure, Esusu/cooperative credit and age.

\section{RESULTS AND DISCUSSION}

Dependent variable $\left(\mathrm{Y}_{1}\right)$ : The adoption index for each respondent was determined by calculating the total number of recommended practices the farmer had adopted for the production of rice. In developing the adoption score a respondent scores one for each recommended practices adopted.

\section{Independent variables}

Extension contact $\left(\mathbf{x}_{1}\right)$ : The extension contact is measured in terms of the frequency of visits of the extension agent to the respondent farmer. It is accepted as basis for reasoning that the relationship between extension contact score and adoption of high-yielding varieties of rice will be positive. This is because farmers who are in frequent contact with the extension agents are likely to be relatively more enlightened and aware of the benefits of adopting high-yielding varieties of rice.

Mass communication media exposure $\left(\mathrm{x}_{2}\right)$ : Mass media exposure for farmers was explained by his access to and use of various mass media. For purposes of analysis, this study used agricultural radio programme. The farmers were asked whether or not they listened to the radio and if so how frequently. It is postulated that adoption index and mass media exposure are positively correlated.

For instance, at the awareness stage, mass media are theoretically supposed to be the most important source of information to farmers on adoption of agricultural innovations. So, one will expect the coefficient of mass communication media exposure to have a positive sign.

Esusu/cooperative credit $\left(\mathbf{x}_{\mathbf{3}}\right)$ : The importance of Esusu/cooperative credit in adoption is as a result of inadequate capital from other sources and the relatively low rate of interest charges on Esusu/cooperative credit
(Odoemenem, 2004). It is therefore, postulated that the relationship between adoption of new varieties of rice and Esusu/cooperative credit will be positive.

Age $\left(\mathbf{X}_{4}\right)$ : One will expect the younger farmers to adopt more than the older ones. Finally, one may expect the relationship between adoption index for rice production and age to have inequality sign.

Production practices: In the study area, the types of rice grown are swamp, upland and floating rice. The upland rice can be grown on normal farm land with adequate rainfall. The common varieties grown among the smallscale farmers are $056, \mathrm{~B} 79-578$, etc. Whereas, the varieties grown under irrigated condition are 1R8, FARD 15, 16, 19 and 21 .

On the other hand, FARD 14 is grown under deep floated condition. The small-scale farmers studied produced their rice by sole cropping regardless of what rice varieties they grow. The experimental rice production practice include planting rice sole crop clearing and terrestrial earth work operation which include, land leveling, construction of irrigation canals and construction of bunds.

The nursery consisting of a fertile, moist seed beds is necessary for swamp rice. However, weeding after 2 weeks and then 3-4 weeks before harvest and closer spacing are important especially if the nutrient status of the soil on which the rice planted is low. Most rice varieties benefit from fertilizer application. Growing resistant varieties of rice helps in controlling blast, narrow brown leaf spot and rice smut diseases. Birds are probably the worst pest of rice. However, scar crows are used to exclude small seed eating birds.

Maturity of different varieties of rice grown in the area of study range from 80-200 days and these are classified as short duration, 120-150 days for medium while $>150$ days are for long duration rice.

Constraints to increasing rice production: The most important constraints to rice production as perceived by our respondents are crop diseases and pests (Table 1). Such diseases include blast, narrow brown leaf spot, rice smut and iron toxicity diseases.

The pests are the birds, borers and rodents. Blast is a fungal disease which causes the infected plant to develop oval-shape red spots on the leaves and results in poor green quality. Infected rice plant by narrow brown leaf spot, develop long attacks on the grains and turns them into a mass black spores. Iron toxicity leads to a red dish-brown discoloration of the leaves 
Agric. J., 5(4): 264-268, 2010

Table 1: Constraints to increasing rice production

\begin{tabular}{lcc}
\hline Constraints & Number & Percentage \\
\hline Disease & 56 & 37.3 \\
Timing & 8 & 5.3 \\
Labour & 25 & 16.7 \\
Fertilizer & 9 & 6.0 \\
Weather & 6 & 4.0 \\
Weed & 4 & 2.7 \\
Pest & 36 & 24.0 \\
Don't know & 6 & 4.0 \\
Total & 150 & 100.0 \\
\hline
\end{tabular}

Field survey, 2008

and sterile particles, thus causing yield reduction whereas birds reduce yield by attacking the rice plants from the milk stage until harvest and borers attack tillering rice in large number causing stem damage and dead tilters. Table 1 shows that about $7 \%$ of the respondent farmers consider labour to be another constraint to rice production.

From this study, farmers complained that scarcity of fertilizer was in existence in their local market. However, $35 \%$ of the respondent farmers reported that local rice variety did not respond to very much fertilizer when compared to improved rice varieties. The next important constraint to rice production as perceived by the respondents is crop disease $(37.3 \%)$ and pests $(24.0 \%)$.

Recommended rice production practices: Each of the respondent farmers who grew rice as his/her major enterprise was asked to describe the practices he/she followed regularly. Practices are shown in Table 2.

About 156 or $97.3 \%$ of the respondent farmers produced rice as sole-crop in their plots while 4 or $2.7 \%$ produce rice as mixed crop. A good number of $96 \%$ did not use nursery beds for their upland cultivation. About $87 \%$ of the respondent farmers performed land leveling and construction of irrigation canals and bunds accounted for about $59 \%$.

Only $52 \%$ of the respondent farmers used fertilizer, insecticides and herbicides on their farms and $48 \%$ of the respondents did not apply chemicals and fertilizers in their rice farms. About $47 \%$ of the respondents did weed their rice plots 4 times during the farming season; $37 \%$ did weed 3 times; 10\% weed twice while about $7 \%$ did not remember how many times they weed their rice plot during the farming season in review.

Respondent farmers enumerated reason for following recommended practices in Table 2. These include direct personal contact with extension officers and friends and visiting a demonstration farm. About $88 \%$ of the farmers indicated that the demonstration farm visit and regular extension officers were the reasons why they decided to try the new methods. Only $14 \%$ of the farmers stated that they decided to follow the practices because they
Table 2: Recommended rice production practices

\begin{tabular}{|c|c|c|}
\hline Practices & Number & Percentage \\
\hline \multicolumn{3}{|l|}{ Production } \\
\hline Mixed & 4 & 27.0 \\
\hline Sole crop & 146 & 97.3 \\
\hline \multicolumn{3}{|l|}{ Swamp rice } \\
\hline Yes & 139 & 90.7 \\
\hline No & 14 & 9.3 \\
\hline \multicolumn{3}{|l|}{ Land leveling } \\
\hline Yes & 130 & 86.7 \\
\hline No & 20 & 13.3 \\
\hline \multicolumn{3}{|c|}{ Irrigation, canal and bunds } \\
\hline Yes & 88 & 58.7 \\
\hline No & 62 & 41.3 \\
\hline \multicolumn{3}{|c|}{ Closer spacing of $25 \mathrm{~cm}$ or less } \\
\hline Yes & 78 & 52.0 \\
\hline No & 72 & 48.0 \\
\hline \multicolumn{3}{|c|}{ Use of fertilizers, insecticides and herbicides } \\
\hline Yes & 78 & 52.0 \\
\hline No & 72 & 48.0 \\
\hline \multicolumn{3}{|l|}{ Scaring of birds } \\
\hline Yes & 120 & 80.0 \\
\hline No & 30 & 20.0 \\
\hline \multicolumn{3}{|c|}{ Frequency of weeding } \\
\hline Never & 0 & 0.0 \\
\hline Twice & 15 & 10.0 \\
\hline Thrice & 55 & 36.7 \\
\hline Four times & 70 & 46.6 \\
\hline Cant remember & 10 & 6.7 \\
\hline
\end{tabular}

Field survey, 2008

Table 3: Reasons given for not adopting practices

\begin{tabular}{lrc}
\hline Reasons & Number & Percentage \\
\hline Did not know about the recommended practices & 50 & 33.3 \\
Cost too much-lack of credit facilities & 23 & 15.3 \\
Did not have necessary equipment & 20 & 13.4 \\
Did not know how to follow recommended practices & 18 & 12.0 \\
Crop could not be sold & 9 & 6.0 \\
Prefer to follow regular methods of production & 10 & 6.0 \\
Did not increase production and/or income & 12 & 8.0 \\
Other reasons & 8 & 5.3 \\
Total & 150 & 100.0 \\
\hline
\end{tabular}

Field survey, 2008

observed a neighbour or friend doing the same thing. The study also asked the respondent farmers reasons for not adopting recommended practices. The number $(33.3 \%)$ of non adopters was that they did not know about the recommended practices (Table 3 ).

The next most frequently mentioned reason was high cost of fertilizers, insecticides, herbicides, combined with lack of credit facilities (15.3\%). Lack of necessary equipment ranked third in importance as can be seen in Table 3. About $12 \%$ of the respondent farmers reported that they did not have necessary equipment to carry out recommended practices for the production of improved varieties of rice.

About $7 \%$ of the farmers preferred to follow the regular methods of production and $8 \%$ felt that the recommended practices did not increase production and/or income. A multiple regression procedure was used to estimate the relationships discussed. The results of the 
Agric. J., 5 (4): 264-268, 2010

Table 4: Estimated multiple regression equation for interrelated factors as

\begin{tabular}{llllccc}
\multicolumn{7}{c}{ determinants of adoption } \\
\hline Constant & \multicolumn{1}{c}{$\mathrm{X}_{1}$} & \multicolumn{1}{c}{$\mathrm{X}_{2}$} & \multicolumn{1}{c}{$\mathrm{X}_{3}$} & $\mathrm{X}_{4}$ & \multicolumn{1}{c}{$\mathrm{R}^{2}$} & $\mathrm{~F}$ \\
\hline 0.3626 & 0.6240 & - & - & - & 0.5792 & 69.8842 \\
& $(0.0960)$ & & & & & \\
-0.3416 & $0.3660^{*}$ & 0.3218 & - & - & 0.4567 & 56.29214 \\
& & $(0.0589)$ & & & & \\
-0.7484 & $0.6932^{*}$ & $0.2478^{*}$ & 0.0737 & & 0.3257 & 38.0276 \\
& $(0.06891)$ & $(0.0624)$ & $(0.0004)$ & & & \\
0.8452 & $-0.7013^{*}$ & $-0.2510^{* *}$ & 0.0743 & 0.305 & 0.3395 & 264274 \\
& $(0.673)$ & $(0.0639)$ & $(0.0004)$ & & & \\
\hline
\end{tabular}

Computer print out from field survey 2008 .*indicates that coefficients are significant at one percent level. Standard errors of coefficient are in parenthesis

analysis are shown in Table 4. The coefficient of all the explanatory variables is positive, thus indicating that extension agents' contacts, mass communication media exposure, Esusu/cooperative credit and age had positive effects on the adoption of rice production.

Considering Table 4 , variable $\mathrm{X}_{1}$ (extension contacts) alone accounted for about $58 \%$ of rice production. And the addition of $\mathrm{X}_{2}$ (mass media exposure) accounted for about $46 \%$. However, addition of $\mathrm{X}_{3}$ and $\mathrm{X}_{4}$ added 0.3257 and 0.3395 , respectively to the variation in adoption.

The regression results shows in Table 4 with $\mathrm{R}^{2}$ of 0.5792 is quite impressive. About $548 \%$ of the variability in adoption of improved variety was explained by the explanatory variables. The result gives a reasonable good fit especially since estimation is from cross sectional data with 150 observations. The F-values of the equation were found to be significant at the $1 \%$ level.

\section{CONCLUSION}

This study investigated the adoption of recommended farm practices of high-yielding varieties of rice among small-scale farmers. Data are obtained through interviews conducted among a total of 150 small-scale farmers drawn from four local government areas of Benue State.

Results show that about $75 \%$ of the farmers were following the recommended farm practices of rice production. Those who have adopted rice production practices are young in age with less number of years of experience in farming but with greater contact with extension agents. Further analysis has shown that extension contact and mass exposure are significantly related to adoption of recommended rice production practices. However, age and Esusu/cooperative credit explained low percentages of the variation in adoption of recommended practices.

The potential advantages from using Esusu/ cooperative credit should not be over-emphasized. Besides the economies of scale and better access to innovation supplies earlier mentioned, the cost of field extension work, as well as time lag between awareness and adoption on innovation can both be greatly reduced. This is so because one extension visit to a cooperative society/Esusu club could replace several visits equal to the number of members present at that meeting.

Finally, efforts should be made to improve the problems of small-scale farmers by making credit available to them as this may improve adoption. A well managed Esusu/cooperative production credit can give agricultural development a strong background by accelerating the rate of adoption of modern improved technologies.

\section{REFERENCES}

BNARDA, 2004. Benue Agricultural and Rural Development Authority. Department For International Development (DFID), Nigeria.

Monu, E.D. and M.M. Omole, 1983. Adoption of recommended farm practices by Nigerian cocoa farmers. Nig. J. Agric. Exten., 1: 45-53.

Nweke, F.I. and J.A. Akerhe, 1983. Determinants of adoption of new technologies among small-holders and implications for administration of transfer programmes: A case study of rice production in the plateau state of Nigeria. Agric. Administration, 12: $77-90$.

Odoemenem, I.U., 2004. Indigenous Savings Mobilization for Rural Women. Nigerian Society of Idigenous Knowledge and Development (NSIKAD), Nigeria, pp: $272-282$.

Osuntogun, A., 1981. Agricultural credit solution to the problems of traditional farmer. J. Rural Sociol., 48: 201-218.

Otitoju, M.A., 2004. The impact of agricultural extension services on rice production in Gwer West local government area of Benue State. Bachelor of Agriculture Degree, Department of Agricultural Economics, University of Agriculture, Makurdi, Nigeria.

Ugwuonah, M.S., 1999. An appraisal of sources of finance to agricultural rural investment: A case study of farmers in Nsukka local government area of Enugu state. Department of Agricultural Economics and Extension, Enugu State University of Science and Technology.

Umebali, E.E. and G. Obinna, 2003. Enhancing sustainable agricultural development through rural credit system: A case study of traditional village associations in Obingwa. Local Government Area of Abia State, Nigeria.

William, S.K.T., 1969. Sources of information on improved farm practices in some selected areas of Western Nigeria. Bull. Rural Econ. Sociol., 4: 30-30. 